\title{
O fruto do desencanto: suicídio e alienação em $A$ maçã envenenada, de Michel Laub
}

Leila Lehnen ${ }^{1}$

Em janeiro de 1993 o grupo norte-americano de rock grunge Nirvana se apresentou no estádio do Morumbi, na cidade de São Paulo. Um pouco mais que um ano depois, em abril de 1994, o líder da banda, Kurt Cobain, suicidou-se em sua casa na cidade de Seattle (EUA). Três dias depois, em 7 de abril de 1994, inicia-se o genocídio de Ruanda. Liderado pela maioria étnica Hutu, este massacre vitimou milhares de pessoas de etnia Tutsi, assim como membros moderados dos Hutu. Estes três eventos são os marcos temporais que organizam - ainda que de forma aberta - o romance do escritor gaúcho Michel Laub, A maçã envenenada (2013).

Como sugere a orelha da primeira edição do romance, trata-se do segundo volume de uma trilogia "sobre os efeitos individuais de catástrofes históricas". Se o primeiro volume, Diário da queda (2011), lidava com a catástrofe e o trauma do Holocausto e os campos de concentração nazistas, A maçã envenenada deixa até certo ponto em aberto qual a catástrofe que impacta os personagens do romance. Os dois eventos supracitados - a morte de Cobain e o genocídio de Ruanda - são trágicos, embora de formas e com impactos muito diferentes. O que os une é que ambos se transformam em instrumentos hermenêuticos, ainda que incompletos e insuficientes, que o protagonista do romance de Laub usa para tentar entender sua tragédia pessoal, o suicídio da primeira namorada após o show do Nirvana no Morumbi. Como se demonstrará neste ensaio, a tragédia individual, lida pela lente das catástrofes coletivas, por sua vez aponta a um horizonte social em crise - tanto nacionalmente, como no âmbito global.

Este artigo propõe uma leitura do romance $A$ maçã envenenada de Michel Laub como uma alegoria do Brasil pós-ditadura. Tendo o suicídio e a tragédia (no sentido de calamidade) como eixos organizadores, o livro de Laub pode ser lido como um comentário sobre o fim de um horizonte utópico no Brasil

Doutora em literatura espanhola e brasileira e professora de literatura e cultura brasileira e hispano americana da University of New Mexico, Albuquerque, Estados Unidos. E-mail: llehnen@unm.edu 
pós-transicional e, de forma mais ampla, em um contexto global. As utopias aqui se referem não somente ao político, mas também à esfera cultural e ao campo da sociabilidade. A maçã envenenada revela a experiência de alienação social e psicológica do protagonista como resultado de uma perda traumática. O processo vivido pelo protagonista do romance de Laub pode ser interpretado como uma alegoria da transformação social que se potencializa no Brasil após a transição democrática de 1985. Ou seja, o isolamento individual do protagonista e a sua melancolia após a perda da primeira namorada remetem, socialmente, à crise das utopias sociais e políticas no contexto pós-transicional brasileiro e internacional, à perda, enfim, da possibilidade de ideais e de engajamento social em nível mais amplo. Dessa forma, ainda que $A$ maçã envenenada pareça ser à primeira vista uma narrativa individualista, a história de uma tragédia pessoal, o romance também pode ser visto como um comentário crítico da conjuntura sociocultural no Brasil e, até certo ponto, no mundo, em começos da década de 1990. O individualismo que transparece no romance serve de certo modo como um comentário indireto da crise de convívio e solidariedade social que se manifesta de forma hedionda em catástrofes históricas como o genocídio de Ruanda.

A componente crítica do romance se evidencia no leitmotiv do texto de Laub - o suicídio. Ato individual, o suicídio, no entanto, também pode refletir circunstâncias sociais mais amplas. Este artigo demonstrará como o romance de Laub usa o suicídio para alegorizar a "derrota" das utopias sociais e políticas em contextos pós-transicionais (Avelar, 1999). Como argumenta Idelber Avelar, essa crise, que ele localiza nas democracias pós-transicionais do Cone Sul, é resultado não somente do trauma provocado pela violência das ditaduras militares em países como o Chile e o Brasil, mas também do processo transicional nestes países e de sua realidade política e econômica após a democratização. Avelar sugere que a realidade política, econômica e, consequentemente social em países como o Chile, o Brasil e a Argentina revela o sucesso das ideologias de direita que impulsionaram os golpes militares. $\mathrm{Ou}$ seja, apesar das transições políticas nestes países, a conjuntura socioeconômica implementada pelos regimes militares continua a ter validade após a redemocratização. O romance de Laub aborda, ainda que de forma indireta, a questão do legado da ditadura não somente na produção literária contemporânea, mas também no imaginário sociocultural brasileiro atual. 
Essas práticas autoritárias aparecem no romance de Laub principalmente na descrição do serviço militar obrigatório cumprido pelo protagonista. Segundo ele: “A vida de quem está no quartel é ser punido" (LAUB, 2013, p. 13).

Refletindo sobre o que ele denomina "alegorias da derrota", Idelber Avelar postula que textos literários pós-ditatoriais que lidam com a perda da memória histórica que acompanha a implementação de regimes neoliberais durante e depois das ditaduras militares no Cone Sul favorecem a figura retórica da alegoria. A alegoria transforma o cadáver no "emblema de uma época" (Avelar, 1999, p. 3). Avelar explica que a pessoa que lamenta a morte de um ente querido se aferra a certos objetos, itens que possam suscitar a lembrança do morto. Para Avelar:

O sujeito que está de luto, assim como o colecionador (duas figuras que Benjamin via como semelhantes), faz uma operação de resgate do ato de lembrar. Seu/sua olhar mudo e melancólico caem sobre um objeto que está separado de todas suas conexões, transformando-o em um emblema daquilo que foi perdido, uma entidade carregada de sentido alegórico (Avelar, 1999, p. 4, tradução nossa).

Avelar observa que a alegoria, entendida como a ruína do passado, um emblema do fim, está inserida dentro de um marco temporal específico, refletindo assim as características de sua época.

Se tomarmos como ponto de partida a definição de alegoria de Avelar, mais especificamente da ficção pós-ditatorial, podemos afirmar que, em $A$ maçã envenenada, a música grunge, particularmente as canções do Nirvana, é o objeto que condensa o luto do protagonista, assim como a melancolia inconsciente de uma geração pelo fim das utopias sociais, culturais e políticas. No romance, a música como alegoria da derrota social e da ruína pessoal do narrador claramente se refere à época em que se popularizou o grunge.

A maçã envenenada conta a história do amor trágico entre o protagonistanarrador e Valéria, sua primeira namorada. O romance é narrado quase exclusivamente na primeira pessoa, sugerindo o egocentrismo do narradorprotagonista e, por extensão, a postura individualista que o romance descreve e ao mesmo tempo critica. A narrativa acontece em um período de 11 meses, entre fevereiro de 1992 e março de 1993, tempo de duração do namoro entre o protagonista e Valéria. O relacionamento e, de certo modo o romance, culminam no concerto do Nirvana no estádio do Morumbi em janeiro de 1993 e o suicídio de Valéria imediatamente após o evento. Durante esses 11 meses, o 
protagonista também cumpre o serviço militar obrigatório no Centro de Preparação de Oficiais da Reserva (CPOR) em Porto Alegre e, juntamente com Valéria e o melhor amigo, Unha, faz parte de uma banda "não muito original" (LAUB, 2013, p. 10) que tocava canções evocativas de composições do segundo álbum do Nirvana, Nevermind (1991). A música representa para Valéria e para o protagonista uma espécie de utopia ao contrário, um romantismo pessimista que esconde a nostalgia por ideais dos dois jovens e de sua geração.

Justapostas à história de amor entre o protagonista e Valéria estão as histórias do suicídio do vocalista do Nirvana, Kurt Cobain, em abril de 1994, e do genocídio de Ruanda. O suicídio de Cobain (e, de certa forma, a história do movimento grunge, simbolizada pelo Nirvana) e o genocídio de Ruanda são uma espécie de pano de fundo alternantes à história do protagonista. Lida à luz de uma ou outra tragédia, a história do protagonista, cujo núcleo é o suicídio, assume diferentes conotações.

O suicídio é o núcleo do qual emana a narrativa de $A$ maçã envenenada. A centralidade dessa temática fica evidente logo no início do romance. O texto abre com uma referência à morte de Cobain: "Um suicídio muda tudo o que seu autor disse, cantou ou escreveu" (LAUB, 2013, p. 7). A voz narrativa sugere que $\mathrm{o}$ ato cometido pelo cantor acabou por determinar o legado do vocalista do Nirvana. O foco no suicídio de Cobain pode ser lido como uma espécie catástrofe anunciada: a história da morte de Valéria e a crise existencial enfrentada pelo protagonista-narrador após este evento.

O suicídio de Cobain também influencia a trama da narrativa, ainda que de forma póstuma. A história do protagonista-narrador e de Valéria e a morte desta parecem assumir outro sentido se lidos vis-à-vis o ato de Cobain - e o que ele representa para os jovens de sua geração. Assim, como no caso do suicídio de Cobain, a morte de Valéria pode assumir um significado mais amplo. Incorporando o ato hermenêutico dentro da própria estrutura narrativa, A maçã envenenada oscila entre várias interpretações para ambas as mortes. No imaginário do narrador-protagonista, os sentidos da/s morte/s se multiplicam, e por vezes se contradizem. Ora elas são lidas como a expressão de um desencanto generalizado, ora como atos profundamente egoístas. O egoísmo do ato pode se visto como um comentário sobre a postura anômica de uma geração, anomia esta causada por uma conjuntura social e cultural específica que será discutida mais adiante. 
Paradoxalmente os eventos que desencadeiam a tragédia no romance - e a tragédia pessoal do narrador - ocorrem antes do suicídio de Cobain. Como indica João Cézar de Castro Rocha na sua resenha de $A$ maçã envenenada, "o tema do romance não pode ser o efeito de um acontecimento epocal na vida de cada um de nós, porém seu impacto na reconstrução que fazemos de nossas intenções e escolhas pretéritas" (RochA, 2014, p. 2). Ou seja, o suicídio de Cobain, o drama individual que se permutou em uma espécie de tragédia coletiva de uma geração (o romance menciona os suicídios em vários países que se seguiram à morte do cantor [LAUB, 2013, p. 18]), articula a reconstrução mnemônica que o protagonista faz para tentar entender a sua história com Valéria e suas próprias decisões depois da morte da namorada.

Não há uma causalidade entre a morte de Cobain e de Valéria, assim como também não entre a morte de Cobain, o drama pessoal do narrador e a história de Immaculée Ilibagiza, uma sobrevivente dos massacres sofridos pela minoria Tutsi em Ruanda em 1994. Mas as três formas de tragédia se entrelaçam ainda que de forma inacabada. Em outras palavras, o suicídio, assim como a música grunge, torna-se uma alegoria da derrota coletiva e pessoal do narrador e de sua geração. Já a história de Immaculée, que sobrevive o massacre dos Tutsis encerrada "noventa dias num banheiro com pouco mais de um metro quadrado, sem pia, na companhia de outras sete mulheres" (LAUB, 2013, p. 17), é uma antípoda, uma outra visão que contrasta com o desencanto emblematizado pela música grunge e pela morte voluntária de Cobain e de Valéria. Em sua narrativa, transmitida pelo narrador-protagonista do romance, Immaculée transforma sua experiência em um processo de aprendizado, em uma conjuntura que a leva à crença no perdão. Para o narrador-protagonista, a sobrevivência de Immaculée e sua posterior capacidade de perdoar àqueles que mataram sua família são os exemplos a serem contrapostos à atitude niilista de Cobain. No entanto, reforçando a ideia da derrota que permeia o romance, esse exemplo, ao mesmo tempo que é admirado pelo protagonista-narrador, também é rechaçado por ele.

É uma entrevista que o protagonista-narrador faz com Immaculée Ilibagiza 20 anos após o massacre de Ruanda e da morte de Kurt Cobain que desencadeia o fluxo da sua memória. A organização fragmentada do romance, com saltos diacrônicos e segmentos curtos que lidam com temáticas que por 
vezes parecem desconexas, emulam por um lado muitas das próprias canções do Nirvana e, por outro o processo mnemônico do indivíduo.

$\mathrm{O}$ foco na memória individual revela também o apagamento de um horizonte histórico coletivo, resultado de um obscurecimento mnemônico promovido pela lógica do mercado (Avelar, 1999) que impera na época em que ocorre o romance. A ideia do apagamento de um horizonte histórico fica evidente na recepção dos dois eventos históricos que servem de marcos para a história do protagonista-narrador. Enquanto se informa exaustivamente sobre as circunstâncias da morte de Cobain, o protagonista-narrador somente toma conhecimento dos acontecimentos em Ruanda "dias, talvez semanas depois, e mesmo assim superficialmente" (LAUB, 2013, p. 17). A falta de interesse do protagonista-narrador pela tragédia coletiva e sua obsessão pela tragédia individual refletem seu individualismo, a ideia de que a história pessoal prevalece sobre a coletiva.

Adicionalmente, a estrutura fragmentada do texto conota o trauma experimentado pelo narrador e, de forma mais indireta/alegórica, o trauma histórico a que o romance alude. Por um lado, o trauma desestrutura a experiência de vida do protagonista. Por outro, a fragmentação demonstra como os traumas coletivos, aliados à falta de uma memória/história coletiva, rompem o entendimento histórico relacionado à catástrofe. Desse modo, ainda que o confronto com a história da sobrevivente do massacre de Ruanda faça o protagonista refletir sobre o significado de seu próprio trauma, em última instância, a tragédia histórica somente parece cobrar significado em relação ao sofrimento particular. Há uma espécie de triangulação por parte do narrador, que procura tanto na morte do cantor, como na sobrevivência de Immaculée Ilibagiza, uma explicação para a sua própria tragédia: o suicídio de Valéria após o show do Nirvana no Morumbi e sua própria tentativa de matar-se após receber um cartão de aniversário póstumo da namorada.

De certa forma pode-se afirmar que o romance em análise é o resultado da reflexão do protagonista a respeito dos acontecimentos de 1993-1994. Ou seja, como sugere Leonardo Petersen Lamha (2013) em sua resenha do livro de Laub, a escritura é uma forma de entender o que aconteceu há 20 anos. Mas, como indica Lamha, essa tentativa de compreensão é posta em xeque na própria narrativa. Usando a voz de Valéria, o romance desconstrói a ideia que o protagonista realmente esteja interessado em entender a namorada morta: “ $O$ 
que importa é isso, não é mesmo? Se você sofreu ou não. ... Alguma vez você se envolveu de verdade com alguma coisa? Você já gostou de alguém de verdade? Já fez algum sacrifício por outra pessoa? Abriu mão de alguma coisa valiosa? Deu alguma prova? Aceitou perder uma única vez? Digo perder de verdade, sem a recompensa de ser vítima" (LAUB, 2013, p. 107). As palavras de Valéria transformam o luto do protagonista, sua reflexão, em uma forma de narcisismo mórbido. Para o filósofo francês Gilles Lipovetsky, o narcisismo - resultado do que ele chama de "personalização" - é uma característica dominante da contemporaneidade. Lipovetsky declara que o narcisismo "surge da deserção generalizada dos valores e finalidades sociais, provocada pelo processo de personalização. O abandono dos grandes sistemas de sentido e a hiper inversão no Eu são as duas caras de uma mesma moeda" (Lipovestky, 1986, p. 53, tradução nossa). Em A maçã envenenada, a ideia do "eu" exacerbado evidenciase também na fetichização de Valéria em um emblema da individualidade do narrador. Para ele a lembrança de Valéria não serve para explicar "o passado dela, que foi enterrado no dia do show do Nirvana, e sim o futuro do lado que sobreviveu: quem eu sou de verdade" (LAUB, 2013, p. 112). Valéria se transforma assim na "alegoria da derrota" pessoal do narrador, ela explica sua inadequação não somente imediatamente após o suicídio dela, mas, como sugere o romance, também a longo prazo.

A história de Valéria e do protagonista pode ser interpretada como a idealização da postura anômica emblematizada por algumas das canções do Nirvana, como Smells like teen spirit, que proclama o (anti)ideal do "perdedor" ao mesmo tempo que, implicitamente, lamenta esse posicionamento ("É divertido perder e fazer de conta / Ela está entediada demais e segura de si”). Essa idealização da anomia decorre de dois fatores: o mito do artista atormentado, narrativa adotada por Valéria como um paradigma a ser seguido, e a descrença em um futuro que seja significativo. Repetidamente o romance alude ao futuro como uma cifra em branco ("não sei”), uma incógnita permanente.

A maçã envenenada indica que a mitologia trágica de figuras como Janis Joplin, Jimi Hendrix e Sid Vicious são uma espécie de referencial trágico para Valéria. A voz narrativa, implicitamente contrastando essas narrativas à história de Immaculée Illibigiza, compara essas referências a uma espécie de “autoajuda ao contrário" (LAUB, 2013, p. 65), sugerindo o horizonte anômico 
que influencia a percepção e, em última instância, as ações de Valéria. O suicídio é visto como uma alternativa "romântica" a uma crise pessoal, o reflexo de uma alma incompreendida pelo mundo em que vive. A essa percepção, a voz narrativa contrapõe cinicamente que "nenhum ídolo da música chega ao pico da popularidade e interesse como o que conscientemente procura o fim” (LAUB, 2013, p. 70). A constatação nega a noção de incompreensão ao justapô-la a uma realidade material que, de certa forma, valida o suicídio em certas circunstâncias usando justamente o discurso do artista atormentado por exigências materiais. Há uma crítica aqui não somente à postura de artistas como Cobain (e de seus seguidores), mas também a um sistema em que a lógica do consumo permeia inclusive o campo da morte, transformando esta em uma possibilidade de lucro.

A fascinação de Valéria pelas vidas trágicas de vários ídolos do rock também exprime parcialmente a transformação de paradigmas sociais. Ou seja, a voz narrativa desconstrói o suicídio como um ato heroico, apontando à sua motivação no fundo egoísta. O romance de Laub sugere que dentro da conjuntura atual ("redes sociais" [LAUB, 2013, p. 70]), o comportamento antissocial se torna o padrão preferido de conduta. A idealização do comportamento antissocial reflete uma desconexão entre o indivíduo e a coletividade - um dos predicados da chamada "modernidade líquida" (BAUMAN, 200o). A separação entre indivíduo e coletividade aguça o individualismo e o niilismo político e social. Assim, A maçã envenenada ao mesmo tempo que mistifica o universo romanticamente niilista de bandas de rock como o Nirvana, também desmistifica essa postura como uma expressão de um sujeito egocêntrico e de uma sociabilidade em crise.

Novamente a figura de Immaculée Illibigiza é usada como uma antípoda ao paradigma do sujeito antissocial como uma figura romantizada. O contraste entre o desejo de sobreviver de Immaculée e o de morrer de Cobain (e, implicitamente de Valéria), de certa forma, critica o desencanto geracional simbolizado pelo suicídio do cantor. No romance de Laub, o cadáver de Cobain e, por extensão, de Valéria transformam-se em um emblema de uma época desencantada. A antinomia entre a morte e o instinto de sobrevivência também critica a própria alienação do narrador. Embora ele, em várias instâncias, exprobre a conduta de Cobain e de Valéria, sua própria postura o desmascara como um indivíduo autocentrado. 
O narrador-protagonista questiona se o desfecho da história de Valéria teria sido outro caso no panteão de seus ídolos estivesse uma figura como a Immaculée. A história da sobrevivente Tutsi é vista como uma alternativa (impossível) para Valéria, uma forma de salvação inexecutável. O autor imagina a reação de Valéria à narrativa da sobrevivente Tutsi: "Eu era a prova viva que tem o pensamento positivo: essa frase soa ingênua para você, Valéria? Fui poupada para mostrar ao maior número de pessoas a Sua misericórdia: você considera cafona essa passagem, Valéria?" (LAUB, 2013, p. 102). A impossibilidade de identific ação de Valéria (e, implicitamente, do protagonista-narrador) com a história de Immaculée, bem como sua rejeição às ideias desta, transmite a postura desencantada dos dois jovens, a falta de uma crença em uma futuridade.

Como sugere Beatriz Rezende, a literatura brasileira contemporânea demonstra uma forte preocupação pelo presente (presentificação). Para Rezende, essa presentificação é reveladora de ceticismo perante projetos utópicos (REZENDE, 2008, p. 26-27). A presentificação esgota o horizonte histórico do sujeito. Se o passado carece de significado, o futuro também esvazia-se. Se para o narrador-protagonista o horizonte histórico, no caso de Valéria, concentra-se na tragédia individual, seu passado também se limita à tragédia pessoal: a morte da mãe, da qual ela quase não se lembra.

Já a perspectiva de futuro de Valéria, que está conectada ao seu passado, também está carregada de um sentimento trágico: a possibilidade de uma doença debilitante, do abandono, da morte. Essa visão revela uma perspectiva individual (ou individualista) e o sentido do trágico que imbui a narrativa de A maçã envenenada. Rezende afirma que, juntamente com a presentificação, o sentido do trágico é outro traço marcante da literatura brasileira contemporânea. O trágico, segundo Rezende, reflete uma conjuntura social mais ampla: a crise do social, a violência do cotidiano, entre outros fatores. Conforme a autora, o trágico invade o cotidiano do sujeito, inclusive as relações pessoais (REzende, 2008, p. 30). No romance de Laub, o suicídio de Valéria e a reação do protagonista frente a esta perda indicam essa prevalência do trágico.

Como indicado anteriormente, no romance o suicídio é a metáfora par excellance da postura alienada simbolizada por Cobain, Valéria e pelo protagonista-narrador. O suicídio representa uma forma exacerbada de 
egotismo. Para o narrador, "o suicídio é uma traição aos outros e a si mesmo, ao que você poderia se tornar no futuro" (LAUB, 2013, p. 103). A futuridade interrompida pelo suicídio representa um déficit duplo: para o indivíduo que comete o ato e para aqueles que o sobrevivem. Como insinua a citação, de certa forma o suicídio também conota um vazio da coletividade.

Para o sociólogo francês Émile Durkheim, o suicídio não é um ato limitado ao âmbito pessoal da vítima/perpetrador e sim a manifestação de vários aspectos sociais que impulsionam o suicida.

Em vez de ver os suicídios apenas como incidentes separados, sem relação entre eles e, consequentemente, como objetos de estudo individuais, os suicídios cometidos em uma sociedade em determinado período de tempo são tomados na sua totalidade, possibilitando ver que esta totalidade não é somente a soma de atos independentes, mas sim um novo fato sui generis, com sua própria unidade, individualidade e, por conseguinte, sua própria natureza, predominantemente social (Durkheim, 1951, p. 46, tradução nossa).

Durkheim estabelece uma categorização dos diferentes tipos de suicídio de acordo com os fatores que motivam o ato. Ele cita o suicídio egotista, o altruísta e o anômico.

Entre os tipos de suicídio que Durkheim discute em seu livro Le suicide (1897) destacam-se o suicídio anômico e o egotista, que são o foco desta análise. O suicídio egotista ocorre, segundo Durkheim, por dois motivos. O primeiro é a desestruturação de crenças e coletividades religiosas devido ao questionamento dos dogmas que estruturam essa crença (DURKHEIM, 1951, p. 169). O segundo motivo para o suicídio egotista é a crise familiar. O suicídio anômico ocorre, segundo Durkheim, quando o núcleo familiar é ou é percebido pelo suicida como fragmentado. Essa conclusão deriva da tese que organiza $L e$ suicide: que o suicídio é um ato em que o individualismo prevalece sobre o espírito de coletividade. Uma comunidade forte (seja ela religiosa, familiar, ou de outra natureza) impõe barreiras ao comportamento individualista e, portanto, ao suicídio. Já uma coletividade enfraquecida não oferece ao indivíduo fortes empecilhos ao suicídio. Durkheim explica essa dinâmica afirmando que:

Os laços que ligam o indivíduo a uma causa comum impedem que ele sinta seus problemas individuais de forma demasiado profunda. Resumindo, existe numa sociedade coesiva e vigorosa uma constante troca de ideias e sentimentos por parte de todos, algo assim como uma ajuda moral mútua. Esta assistência, em vez de fazer com que o indivíduo se apoie somente em si mesmo, leva-o a 
compartilhar da energia coletiva e a desenvolver a sua própria energia quando esta estiver exausta (Durkheim, 1951, p. 209, tradução nossa).

Se o suicídio egotista ocorre como resultado de um individualismo exacerbado, ou seja, de uma crise do indivíduo tomado por este, o suicídio anômico é consequência de uma crise em nível social.

O suicídio anômico acontece quando se desestabiliza o horizonte de expectativas sociais que regula e integra o indivíduo a uma estrutura social, gerando uma crise moral e psicológica no sujeito. Durkheim observa que: "Sempre que haja reajustes profundos na ordem social, devido ou não a um surto de progresso ou uma catástrofe inesperada, os homens se tornam mais propensos à autodestruição" (Durkheim, 1951, p. 246). Para Durkheim, as grandes transformações sociais deixam o sujeito sem parâmetros morais que possam guiar seu comportamento, provocando assim o suicídio. Durkheim explicita que essas transformações não têm que ser necessariamente de índole negativa, pois o que causa o suicídio é o desequilíbrio de padrões econômicos, políticos, morais, psicológicos e sociais anteriormente estáveis.

Em $A$ maçã envenenada, observa-se uma confluência de ambos os tipos de suicídio, o egotista e o anômico. A maçã envenenada busca a explicação para o "problema médico, religioso, filosófico, moral, jurídico" (LAUB, 2013, p. 102) que é o suicídio apontando para as potenciais causas individuais e sociais deste ato. No caso de Valéria, a morte da mãe quando aquela era criança e o posterior medo do abandono servem como explicações possíveis, ainda que incompletas. A morte da mãe, que, conforme sugere o romance, também pode ter sido um suicídio (ou apenas um acidente), desestrutura a experiência afetiva de Valéria, gerando nela sentimentos que oscilam entre o desejo pela presença talvez idealizada - da mãe, e a incompreensão de que a mãe não tivesse se lembrado dela antes de bater o carro que estava dirigindo contra uma árvore: "Valéria é incapaz de dizer qualquer coisa sobre aquela noite porque tudo foi bloqueado na repetição das perguntas, por que a mãe tomou essa decisão, [...] por que ela decidiu acelerar em direção à árvore e me deixar sozinha aqui” (LAUB, 2013, p. 73). A citação sugere que Valéria interpreta as ações da mãe como um ato egoísta. A reiteração da dúvida e o vazio mnemônico em relação à morte da mãe, por sua vez, revelam o trauma da perda em Valéria. A perda, por sua vez, produz em Valéria um profundo sentimento de desamparo, um vazio existencial e um vácuo nas suas 
convivências sociais. É significativo que nos 11 meses que dura seu namoro com o protagonista-narrador, não haja um convívio social mais amplo ("Valéria não me apresentou ao pai, nem mostrou fotos dele ou de qualquer parente" [LAUb, 2013, p. 113]). Sua relação se limita aos dois, um círculo fechado que sugere o isolamento de ambos personagens.

Valéria carrega o seu temor de abandono como uma segunda pele. Suas relações afetivas são vistas pelo prisma desse medo. O receio do abandono torna-se o eixo organizador dos namoros de Valéria. Esse medo, torna-se a proverbial "maçã envenenada", que contamina as relações com o fatalismo do desamparo. Não é à toa que o bilhete de despedida dela cite - incorretamente - a letra da canção Drain you, do Nirvana. A referência à canção transmite a ideia do amor como uma contaminação e uma anulação do indivíduo dentro da relação. O abandono do "eu" em favor de um "nós" idealizado - justamente aquilo que Valéria crê que a mãe não foi capaz de fazer ao "escolher" a morte. No entanto, Valéria traduz incorretamente a terceira estrofe da canção do Nirvana: "You've taught me everything / Without a poison apple" (Você me ensinou tudo / Sem uma maçã envenenada"). Em vez de traduzir o "without" como "sem", ela traduz o verso como "ao me dar a maçã envenenada", eliminando assim a inversão da referência bíblica. A "maçã envenenada" é aqui o proverbial fruto do conhecimento do outro. Ao intuir o abandono pelo outro, esse conhecimento se torna fatal para Valéria.

O narrador-protagonista não sabe se o erro de tradução de Valéria foi de propósito ou apenas o resultado desses "cursos de inglês onde você passa anos falando com o professor e é incapaz de entender duas frases de um filme sem legenda" (LAUB, 2013, p. 99). Como em outras instâncias, ele não tem uma resposta definitiva ao dilema. A ambivalência nesse contexto simboliza a continuação do trauma da perda, pois não oferece uma conclusão satisfatória à tentativa do narrador de entender a Valéria ("A morte de Valéria nunca deixará de ser um mistério, e o cartão-postal pode ter sido apenas uma ideia quando ela passava em frente à agência de correio" [LAUB, 2013, p. 110]). Ou seja, em última instância o romance sugere que não há entendimento possível para a tragédia.

Se a morte de Valéria pode ser interpretada pelo prisma do suicídio anômico, a tentativa de suicídio do narrador meses após o suicídio de Valéria se dá pela junção do luto não resolvido da morte da namorada e o sentimento de culpa não só pela morte dela (ele efetivamente termina o namoro antes de 
que ela se mate), mas também por ter sobrevivido (LAmнA, 2013). Esse sentimento de culpa contamina a sua memória, tornando-se sua própria "maçã envenenada". Durante a entrevista com Immaculée, o protagonista se pergunta como um sobrevivente pode evitar que essa culpa se transforme "em autopiedade e autoindulgência" (LAUB 2013, p. 43). A pergunta espelha a sua própria condição e parte do ímpeto que o leva a tentar se matar e que também impele a escritura da história que estamos lendo.

A tentativa de suicídio do protagonista pode ser lida como uma expressão de "autoindulgência" e, paralelamente, como uma forma de expiar a culpa que ele sente pela morte da (ex-)namorada, desencadeada pelo cartão de aniversário póstumo que ele recebe de Valéria. Instigado pelo cartão, o narrador-protagonista procura a morte como uma espécie de pharmakos. No ritual grego, em tempos de catástrofe, sacrificava-se ou exilava-se uma vítima para a purificação da comunidade e o restabelecimento da ordem. A tentativa de suicídio é uma forma de o narrador-protagonista restabelecer uma ordem a do nada existencial - dentro da condição anômica que o suicídio de Valéria (e antes disso, o relacionamento com esta) gera. $\mathrm{O}$ romance sugere que esse sacrifício, mais do que ser um ato voluntário do narrador-protagonista, tem sua origem na exigência de Valéria. Para ela, o amor é poder "ir até o final", "dar adeus ao que foi sua vida até agora" "entregar tudo o que tem" (LAUB, 2013, p. 66). De certa forma, Valéria parece demandar o sacrifício para, por sua vez, restabelecer a ordem existencial que foi rompida pela morte da mãe. Mas a demanda implícita de Valéria também se relaciona com o romantismo pessimista simbolizado pela música de Cobain e de outros grupos grunge.

Quando a tentativa de suicídio do protagonista malogra - não sabemos se por acaso ou intencionalmente - o protagonista-narrador acaba indo para um exílio simulado. Ele viaja a Londres, onde passa vários meses. Aqui a solidão que caracteriza sua existência depois da morte de Valéria torna-se uma identidade, uma forma de libertação: "e nada do que você disse ou fez a uma pessoa tem consequência porque nunca mais precisará encontrá-la, nem pensar nela, nem imaginar e confrontar o que foi feito dela em outro tempo e outro continente numa vida que às vezes nem parece ter sido a sua" (LAUB, 2013, p. 25). A citação evidencia o ímpeto de não somente livrar-se do passado ("numa vida que às vezes nem parece ter sido a sua"), mas também 
propõe o isolamento como um modus vivendi preferencial. O sujeito não tem mais que se preocupar com laços nem afetivos nem sociais. É significativo que, durante sua estadia em Londres, o protagonista-narrador se isole a ponto de nem mesmo ver televisão ou ler jornais. As únicas notícias que têm relevância para ele são sobre música (LAUB, 2013, p. 17). Ou seja, durante a sua estadia na capital inglesa, o protagonista-narrador existe em um vácuo de sociabilidade. Esse vácuo não somente é o resultado do trauma da perda, mas também de um contexto sociocultural em que se dissolvem os projetos utópicos do século xx.

Assim como o isolamento voluntário do protagonista-narrador, a morte de Valéria também está embutida de um certo Zeitgeist, que se expressa nas canções do Nirvana e cuja metáfora é, de certa forma, o suicídio de Cobain. Em seu apartamento porto-alegrense, Valéria tem um pôster do cantor que emblematiza o romantismo desiludido que transparece nas canções do grupo um "discurso de lamento diante do mundo corrompido, as falas contra violência, sexismo e homofobia que eram uma espécie de crença por baixo de uma capa de niilismo e despretensão" (LAUB, 2013, p. 63).

$\mathrm{O}$ romance oscila entre a crítica e a reiteração das explicações para a morte de Cobain que inserem o seu suicídio no contexto mais amplo da sua produção musical desencantada, paradigmática da postura de toda uma geração. A voz narrativa, afetando distanciamento, afirma que todos ("todo mundo") tinham uma "tese" sobre a música de Cobain, "uma tese sobre como ele incorporou o espírito de uma época esmagada pelo fim das utopias, sobre como uma geração pouco educada devolvia a raiva ao emergir no fim dos anos Reagan, sobre o que era ser jovem numa América tomada por corporações, individualismo e falta de perspectivas" (LAUB, 2013, p. 18). Apesar do distanciamento do protagonista frente à interpretação das canções do Nirvana como uma metáfora de uma geração perdida (a referência a um "todos" em terceira pessoa), as suas palavras implicitamente também aceitam e internalizam a explicação do significado da música de Cobain, e, por extensão, da sua morte. Segundo essa explicação, ambos - música e morte - denotam um horizonte de expectativas extinguido que é internalizado pelo protagonista-narrador. Nesse cenário não há mais idealismos - nem de esquerda, nem de direita. Nesse sentido, a chamada geração x (pessoas nascidas entre 1961-1981), confronta-se com o fim das grandes narrativas sociopolíticas que nortearam gerações anteriores. O fim da Guerra Fria, e com ela a propagação do que 
Frederic Jameson chamou de "capitalismo tardio" (JAMESON, 1991), abalou as dicotomias ideológicas e também socioeconômicas vigentes desde o fim da Segunda Guerra Mundial. No lugar da tensão entre comunismo e capitalismo temos uma "propagação" do ideal capitalista (e mais que isso, do capitalismo neoliberal) que permeia todos os aspectos da vida social, desde o político até o cultural. O romance de Laub sugere essa dinâmica ao citar como uma das possíveis causas da morte de Cobain as pressões do mercado sobre sua produção musical (LAUB, 2013, p. 29).

Para Zygmunt Bauman, a preeminência do lucro sobre vários aspectos da sociedade que impera no neoliberalismo transforma as relações sociais em relações de contratualidade, em que as pessoas são vistas como mercadoria, objetos a serem consumidos (BAUMAN, 2003, p. 7, 12-13). O romance de Laub não alude especificamente à influência neoliberal nas relações de sociabilidade, entretanto o texto aborda o esgarçamento das relações pessoais no contexto dos anos 1990 e início da década de 200o. O protagonista admite que, desde a morte da namorada, teve poucos relacionamentos significativos (LAUB, 2013, p. 25). Sua visão de mundo contaminada pela tragédia da juventude reflete um ennui generalizado: "Nos vinte anos posteriores a $1993 \mathrm{eu}$ eventualmente detestei o trabalho, os relacionamentos que não deram certo, e também me senti triste e exausto, doente e vencido" (LAUB, 2013, p. 88).

No contexto do neoliberalismo e os efeitos socioeconômicos e culturais deste, a perspectiva de futuridade dos membros da Geração x parece limitada. Segundo Bauman, além das dificuldades econômicas enfrentadas por este grupo, seus membros também sofrem de uma desorientação existencial que "assombra" quase todos os membros desta geração e provoca neles uma ansiedade generalizada (BAUmAN, 2004, p. 14). Esta ansiedade é expressada no romance de Laub pelas referências à música de Cobain e pela reiteração do suicídio como Leitmotif, como uma alegoria da derrota.

Além das múltiplas referências a canções do Nirvana (especialmente Smells like teen spirit e Drain you), a voz narrativa também alude à sensibilidade pós-punk que - após o fim da Guerra Fria - critica o capitalismo de forma niilista ("Papai Noel porco capitalista que presenteia os ricos e cospe nos pobres" [LAUb, 2013, p. 36]. Pode-se dizer que o niilismo dessas bandas, que dissimula um romantismo desencantado, é adotado pelos seus fãs, alude ao fim das utopias sociais e políticas que ganha força no final dos anos 1980. 
O protagonista de $A$ maçã envenenada explica que a definição do romantismo em geral "inclui os conceitos de pureza e convicção, o anseio por um ideal que está além da banalidade ou desvirtuamento do tempo em que se vive, o que facilmente deságua em revolta ou loucura” (LAUB, 2013, p. 63).

A aparente falta de ideais que emana das canções do Nirvana e de outras bandas grunge, e que no entanto encobre justamente um anseio romântico de ideias, assume no contexto latino-americano, e mais especificamente brasileiro, um significado adicional se considerarmos que o começo da década de 1990 revela a deficiência dos projetos democráticos que foram (com exceção do Chile, que retorna à democracia apenas em 1990) implementados nos países do Cone Sul em meados/finais dos anos 1980. Esses projetos políticos se caracterizam pelo compromisso entre atores de uma direita autoritária, herdeira dos regimes militares que assolaram países como o Brasil por mais de duas décadas, e de uma esquerda que já não tem as mesmas aspirações sociopolíticas de outrora. Além da desilusão política, a década de 1980 e o começo dos anos 1990 são períodos de profunda crise econômica no Brasil, crise esta que desemboca na implementação de medidas neoliberais que, por sua vez, exacerbam problemáticas sociais, tais como a desigualdade socioeconômica.

Apesar ou talvez devido a essa conjuntura de crise, temos também a solidificação da cultura de consumo no país e a propagação de uma consciência globalizante dentro da produção cultural brasileira. Em seu ensaio sobre a geração x no Brasil e no México, William Garcia demonstra como a esfera cultural latino-americana reflete a conjunção entre pessimismo e consumismo. Ele enumera entre os temas que são abordados na produção cultural da geração $\mathrm{x}$ os efeitos do neoliberalismo e da cultura de consumo promovida por essa ideologia (GARCIA, 2012). Garcia também observa que em muitas dessas produções aparecem personagens estrangeiras e/ou transnacionais, refletindo a consciência do processo de globalização que acelera após o fim da Guerra Fria. A maçã envenenada ecoa essa sensibilidade globalizada ao inserir as histórias de Cobain e de Immaculée Illibagiza dentro da narrativa. Especialmente o cantor do Nirvana torna-se um símbolo da identificação transnacional da juventude brasileira. Pode-se argumentar que essa sensibilidade globalizada no romance revela um abandono (ou descaso) com a produção cultural nacional (não há quase menção a grupos musicais 
nacionais no romance) e, implicitamente, sugere uma falta de interesse pela temática/problemática nacional.

O romance de Laub também alude ao contexto sociocultural da cultura de consumo global que se propaga pelo Brasil nos anos 1990. Espalham-se os shoppings e os restaurantes fast food no Brasil, e a juventude da época usa roupas de marca e bens culturais como o conhecimento sobre bandas de rock estrangeiras como marcas de distinção. O protagonista alude a essa diferenciação mencionando o gosto - na opinião dele deplorável - de seus colegas, que escutavam "bandas australianas que apareciam dirigindo carros esporte com mulheres de biquíni” (LAUB, 2013, p. 36). Enquanto isso, embora sendo da mesma classe social, ou seja, também "frequentasse escola particular e tivesse uma empregada que trazia queijo-quente e milk-shake no meio da tarde” (LAub, 2013, p. 36) ele se identifica com a cultura e a ideologia anticapitalista de grupos punk como Olho Seco ou as supracitadas "bandas anticapitalistas". A aposição entre a cotidianidade do protagonista e sua identificação musical é irônica, indicando-nos a alienação deste em relação ao seu contexto sociopolítico. As mensagens das músicas punk são para ele apenas uma forma de se distinguir dos colegas, não necessariamente um comentário social. Como indica Lipovetsky, o individualismo promove a busca não de uma identidade coletiva e sim de identificações pessoais. Há uma fragmentação do imaginário coletivo. No vazio dessa coletividade inserem-se narrativas e identidades individuais/individualistas ou então "tribalistas" (MAfFEsoli, 1996). Essa imagem de fragmentação e individualismo é iterada também na interpretação que o protagonista-narrador faz das canções do Nirvana "versos fragmentados com ressonâncias de histórias e sentimentos que os fãs intuíam ou sabiam por outras fontes, tudo suficientemente vago para adquirir os sentidos que cada um escolhesse" (LAUB, 2013, p. 29). O substrato cultural comum ("outras fontes") somente ganha relevância na interpretação individual, não em uma possível mensagem coletiva que possa transmitir as canções do grupo. A única mensagem coletiva que transparece é a do isolamento e do desencanto.

Refletindo a alienação do protagonista, $A$ maçã envenenada não menciona diretamente nenhuma das problemáticas sociais da época. A contextualização no romance limita-se quase somente a referências globais, à discussão do 
panorama musical internacional e à menção (passageira) do genocídio de Ruanda. No entanto, pode-se dizer que o quase-silêncio a respeito do contexto social, político e econômico brasileiro (e mundial) funciona não somente como uma metáfora de uma sensibilidade globalizada que toma força a partir do começo da década de 1990, mas também do desengajamento provocado - em parte pelo menos - por um desencanto social e político. A falta de contextualização se traduz também em uma falta de convicção ideológica nem o narrador nem Valéria acreditam em "deus”, nem tão pouco em causas políticas. O narrador não se lembra de que a namorada tenha defendido "um partido, uma causa, uma ideia com convicção que fosse” (LAUB, 2013, p. 114). Essa falta de engajamento é significativa se consideramos o momento histórico em que transcorre o romance.

Estamos em 1992/93. Mas a voz narrativa ao mesmo tempo que - ainda que de forma muito passageira - mapeia o panorama social e político da época: o fim da ditadura, as eleições diretas, o impeachment de Fernando Collor de Mello, afirma que nada disso importava para alguém que "morava com os pais e tinha uma guitarra e fazia parte de uma banda como eu" (LAUB, 2013, p. 8). Oalienamento do protagonista implicitamente revela a decepção ("nada importava") de uma geração que votou pela primeira vez nas primeiras eleições diretas em mais de duas décadas e que viu essa escolha desencaminhar pela corrupção política. É também a desilusão de um país onde a crise econômica da década anterior e dos primeiros anos da década de 1990 põe em suspenso os projetos de futuro da geração que está chegando à idade adulta nessa época. Não há, no romance de Laub, projetos de futuridade. A eleição do suicídio como tema central indica um futuro truncado.

Além do mapeamento superficial de alguns dos eventos políticos mais importantes da época mencionados anteriormente, A maçã envenenada somente alude ao panorama social e político brasileiro ao tematizar o serviço militar obrigatório do protagonista. O serviço militar insinua tanto o legado da ditadura, como o espólio desta - a descrença não só na instituição militar, mas também da ideia de que seja possível inserir-se num panorama ideológico significativo, seja ele político ou social. O exército é descrito como uma instituição obsoleta dentro de um país que parece não existir além do horizonte individual de cada um dos personagens do romance. Ao mesmo tempo, a descrição do cotidiano no serviço militar revela a cultura autoritária que ainda impregna essa instituição. O legado autoritário aparece repetidamente na 
descrição da rotina do quartel - desde os rituais diários em que o corpo é treinado e a individualidade apagada - até a arbitrariedade das decisões de superiores. A voz narrativa mais registra a cultura militar do que a critica. Reforçando a alienação generalizada do protagonista-narrador, no quartel sua postura é de passividade frente aos abusos que são cometidos em nome da disciplina. A única insurreição do protagonista contra as regras do quartel se dá quando este fuma maconha com um companheiro de serviço. Este ato por sua vez somente cobra importância quando interpretado pelo viés da experiência individual. Sua transgressão impede o protagonista-narrador de ir com Valéria ao show do Nirvana em São Paulo, pois ele tem que comprar o silêncio do companheiro quando este é flagrado com o baseado (o protagonista sai "do beco um minuto antes do flagrante, talvez menos que isso, trinta segundos ou o suficiente para que não fosse visto" [LAUB, 2013, p. 21]).

Para o protagonista-narrador, a decadência do quartel, a futilidade do serviço militar são símbolos da sua derrota pessoal - o desenlace infeliz do primeiro amor, a derrota de um idealismo travestido de niilismo representado no suicídio de Valéria e de Kurt Cobain. Reforçando o tom individualista do romance, o protagonista-narrador parece interpretar o serviço militar não como um legado de um sistema obsoleto, mas sim como uma afronta pessoal: "o que estou fazendo neste lugar, por que preciso estar aqui aos dezoito anos, tendo passado num dos vestibulares mais difíceis do Rio Grande do Sul, e eu de gorro e arma na mão, protegendo um quartel pobre contra um inimigo que nunca existiu" (Laub, 2013, p. 31). No entanto, apesar da ênfase no "eu", evidenciada pelo uso da primeira pessoa singular, a citação indiretamente conecta o pessoal com o social. A futilidade que o protagonista-narrador sente emana, em parte pelo menos, do vazio ideológico ("inimigo que nunca existiu") que permeia não somente a ideia do serviço militar, mas também uma sociedade.

Em Alegorias da derrota: a ficção pós-ditatorial e o trabalho do luto na América Latina, Idelber Avelar (1999) propõe a ruína como a alegoria da derrota dos projetos de esquerda pela lógica de mercado implementada pelos regimes autoritários latino-americanos nas décadas de 1960 e 1970. A maçã envenenada usa o suicídio como uma alegoria do legado dessa derrota. No panorama brasileiro pós-ditatorial, a crise individual encapsula uma crise maior que se expressa na música da época, o grunge desencantado. Mas o 
suicídio também representa um ato egoísta, a metáfora do indivíduo alienado, do sujeito abstraído de uma coletividade em ruínas.

\section{Referências}

Avelar, Idelber. The untimely present: postdictatorial Latin American fiction and the task of mourning. Durham, NC: Duke University Press, 1999.

Bauman, Zygmunt. Liquid modernity. Malden, MA: Polity Press, 2000.

Bauman, Zygmunt. Liquid love. Malden, MA: Polity Press. 2003.

Bauman, Zygmunt. Wasted lives: modernity and its outcasts. Malden, MA: Polity Press, 2004.

Cobain, Kurt. Drain you. In: Nirvana. Nevermind. Van Nuys, CA: DGC Records, 1991. 1 cD. Faixa 8.

Cobain, Kurt; Grohl, Dave; Novoselic, Krist. Smells like teen spirit. In: Nirvana. Nevermind. Van Nuys, CA: DGC Records, 1991. 1 cD. Faixa 1.

Durкherm, Émile. Suicide: a study in sociology. Glencoe, Ill: Free Press,1951.

GARCIA, William. Young, sexy and transnational in Mexico and Brazil: commodifying the generation x in Antonio Serrano's Sexo, pudor y lágrimas and its film versions. In: Henseler, Christine. Generation x goes global: mapping a youth culture in motion. New York: Routledge, 2012, p. 91-112.

Jameson, Frederic. (1991). Postmodernism, or, The cultural logic of late capitalism. New York; London: Verso.

Lamha, Leonardo P. Maçã bichada. fornal Rascunho, Curitiba, out. 2013. Resenha. Disponível em: <http://rascunho.gazetadopovo.com.br/maca-bichada/>. Acesso em: 16 maio 2014.

LAub, Michel. A maçã envenenada. São Paulo: Companhia das Letras, 2013.

Lipovestry, Gilles. La era del vacío. Tradução de Joan Vinyoli e Michèle Pendanx. Barcelona: Anagrama, 1986.

Maffesoli, Michel. The time of the tribes: the decline of individualism in mass society. London; New York: Sage, 1996.

Rezende, Beatriz. Contemporâneos: expressões da literatura brasileira no século xxi. Rio de Janeiro: Casa da Palavra, 2008.

Rocha, João Cézar de Castro. O Estado de S. Paulo. 24 jan. 2014. Disponível em: $<$ http://cultura.estadao.com.br/noticias/geral,michel-laub-lanca-segundo-volume-detrilogia,1122606 >. Acesso em: 20 maio 2014.

Recebido em 28 de janeiro de 2017.

Aprovado em 7 de março de 2017. 


\section{Resumo/Abstract/Resumen}

O fruto do desencanto: suicídio e alienação em $A$ maçã envenenada, de Michel
Laub Leila Lehnen

Este artigo propõe uma leitura do romance $A$ maçã envenenada (2013) de Michel Laub como uma alegoria do Brasil pós-ditadura. Tendo o suicídio e a tragédia (no sentido de calamidade) como eixo organizador, o livro pode ser lido como a alegoria da derrota (Avelar, 1999) que indica o fim de uma coletividade e, em termos mais amplos, o fim das utopias sociais e políticas no contexto pós-transicional brasileiro. Este artigo demonstrará como o romance de Laub usa o suicídio para alegorizar a "derrota" das utopias sociais e políticas, resultado não somente da ditadura, mas também do processo transicional brasileiro e da realidade política e econômica do país após a democratização.

Palavras-chave: suicídio, tragédia, política, Michel Laub.

The fruit of disenchantment: suicide and alienation in Michel Laub's $A$ maçã envenenada

Leila Lehnen

This article proposes to read Michel Laub's novel A maçã envenenada (The poisoned apple, 2013) as an allegory of post-transitional Brazil. Using the themes of suicide and tragedy (as a synonym of calamity) as thematic anchors, the essay reads Laub's text as an allegory of defeat (AvELAR, 1999). This allegorical portrayal suggests the end of a sense of collectivity and, in general terms, the demise of social and political utopias in post-transitional Brazil. The article thus proposes that, in Laub's novel, the trope of suicide allegorizes the "defeat" of social and political utopias as a result not only of the dictatorship, but also of the problematic transition to democracy and finally of the country's social and political reality after the democratization.

Keywords: suicide, tragedy, politics, Michel Laub.

El fruto del desencanto: suicidio y alienación en Michel Laub's $A$ maçã envenenada

Leila Lehnen

Este artículo propone una lectura de la novela de Michel Laub A maçã envenenada (La manzana envenenada, 2013) como una alegoría del Brasil postransicional. Usando los tropos del suicidio y de la tragedia (en el sentido de calamidad) como ejes organizadores, se leerá la novela de Laub como una alegoría de la derrota (AvELAR, 1999). La alegoría trazada en el texto señala hacia el fin de la colectividad y, en términos más generales, el derrocamiento de las utopías sociales y políticas en el Brasil postransicional. Se demostrará que en la novela de Laub el suicidio alegoriza el fracaso de las utopías sociales y políticas como resultado no solamente de la experiencia dictatorial, sino también de la transición democrática y de la realidad social y política después de la democratización.

Palabras clave: suicidio, tragedia, política, Michel Laub. 